\title{
Smoking, consumption of alcohol and sedentary life style in population grouping and their relationships with lipemic disorders*
}

\author{
Ignez Salas Martins, Leda Teixeira Coelho, \\ Monica Inés Casajus, Elisa Tieko Okani
}

\author{
Department of Nutrition, School of Public Health. University of S. Paulo - Brazil
}

\begin{abstract}
The study, part of the project "Atherosclerotic cardiovascular diseases, lipemic disorders, hypertension, obesity and diabetis mellitus in a population of the metropolitan area of the southeastern region of Brazil", had the following objectives: a) the characterization and distribution among typical human socio-economic groupings, of the prevalence of some particular habits which constitute aspects of life-style-the use of tobacco, the use of alcohol and sedentary activity; b) the establishment of the interrelation between the above-mentioned hablts and some lipemic dlsorders. The prevalence of the habits cited behaved in the following manner: the use of tobacco predominated among men, distributed uniformly throughout the soclal strata; among the women the average percentage of smokers was $18,9 \%$, a significant difference occurrlng among the highest soclo-economic class, where the average was of $40.2 \%$. The sedentary style of life presented high prevalence, among both men and women with exception of the women of the highest socio-economic level and of the skilled working class. The use of alcohol, as one would expect, is a habit basically practised by the men, without any statistically significant differences between classes. For the purpose of establishing associations between these rlsk fictors and lipemic conditlons four situations were chosen, of the following characteristics: 1 - total cholesterol $>=220 \mathrm{mg} / \mathrm{dl}$ and triglycerldes $>=150 \mathrm{mg} / \mathrm{dl} ; 2$ - HDL cholesterol $<35 \mathrm{mg} / \mathrm{dl}$ for men and $<45 \mathrm{mg} / \mathrm{dl}$ for women and triglycerides levels $>=150 \mathrm{mg} / \mathrm{dl}$; $3-\mathrm{HDL}$ cholesterol $<35 \mathrm{mg} / \mathrm{dl}$ for $\mathrm{men}$ and $<45 \mathrm{mg} / \mathrm{dl}$ for women and triglycerides levels $<150 \mathrm{mg} / \mathrm{dl} ; 4$ - total cholesterol $220 \mathrm{mg} / \mathrm{dl}$ with triglycerides levels $<150 \mathrm{mg} / \mathrm{dl}$. Six models of multiple (backward) regression were established, with seven Independent variables- age, sex, use of tobacco, consumption of alcohol, light physical activity, hypertension and obesity. Significant associations $(P<0,05)$ were revealed with hypercholesterolemia, accompanied by trigiyceride leveis $>=150 \mathrm{mg} / \mathrm{dl}$, and the following independent varlables: age, use of tobacco and the interactions between obesity and smoking, age and sedentary life. style, sex and obeslty (R2=22\%); the standardized B coefficient showed that the variables with the greatest weight in the forecasting of the variation in the levels of cholesterol were smoking and the interaction between obesity and smoking. The hypercholesterolemla accompanied by triglycerides levels $<150 \mathrm{mg} / \mathrm{dl}$ showed a positive association between total cholesterol and sex and the interactions obesity/smoking and sex/obesity. As regards HDL cholesterol accompanied by triglyceride/ levels > $=150 \mathrm{mg} / \mathrm{dl}$ was inversely associated with obesity and the interaction smoking/ age and directly with age $(\mathrm{A}=31 \%)$. The standardized $\mathrm{B}$ coeffients, indicated that the variables obesity and the interactions smoking/age possessed a weight three times greater than age alone in accounting for the variation In the serum levels of HDL cholesterol. When accompanied by triglycerides $<150 \mathrm{mg} / \mathrm{dl}$ there was no association between and the independent variables and the set of them presented $\mathrm{R}$ equal to $22 \%$. The sum of top, in the population stutied In this project, the component habits of life-style (smoking, alcohol consumption and sedentary activity) whlch constitute risk factors which determine morbidity from atheroschlerotic cardlovascular diseases are be tound distributed through all the typlcal soclal groupings of this partlcular form of soctal organization. On the other hand, the seven independent variables used in the multiple regression models for the explanation of the lipernic conditions considered presented multiple determination coefficients which varied, approximately, between $20 \%$ and $30 \%$. Thus it ls important that in the genetic epidemlology the study of the morbidities in question be emphasized.
\end{abstract}

Smoking, epidemiology. Alcoholism, epldemiology. Life style. Hyperlipidemia, epidemiology.

\footnotetext{
* Supported by "Fundaçāo de Amparo à Pesquisa do Estado de Säo Paulo (FAPESP)" (Process n" $91 / 0820-7$ and "Conselho Nacional de Desenvolvimento Científico e Tecnológico (CNP4)" (Process n "410427/89-6).

Reprints: Ignez Salas Martins - Av. Dr. Arnaldo, 715 - 01246-904 - S. Paulo, SP - Brazil

The publication of this article was suported by FAPESP. (Process 94/0500-0).
}

Submined in 4.20.1994. Approved in 11.29.1994. 


\section{Introduction}

Life styles imply certain habits of living and forms of physical wear and tear in biological terms at the individual level within the specific group of a particular social formation.

Thus, labouring activities, kinds of nutrition and other culturally legitimated habits create life styles related to the factors which constitute physical environment and act on the human organisms in their search for ways of adaptation and vital balance. However, homeostasis is not always compatible with the potential longevity of the species as there exist within the life-styles risk factors related to morbidities which may lead to premature death. This is the case with atherosclerotic cardiovascular diseases among the etiological causes of which are to be found factors such as lipemic disorders, hypertension and obesity.

In their turn lipemic disorders, hypertension and obesity are morbidities generally associated among themselves and among whose causes are factors of a genetic and social nature.

Among these smoking habits may be observed, as well as the consumption of alcohol, sedentary life ${ }^{11,12,14,16,24,26,31}$.

Therefore the clarification of the link between habits and morbidities leads, in the first place, to the characterization of the distinctions between prevalencies of the same between typical human groupings; afterwards to stablish assotiations among habits and morbidities.

In accordance with this reasoning the present study project seeks: a) to characterize the differentials regarding the prevalence of smoking, consumption of alcohol, sedentary life style in human groupings, and b) to analyse some of the inter-relationships among smoking, alcohol consumption, sedentary life style and particular lipemic states - that is to say, how the habits are associated with particular lipemic situations as predictive variables.

\section{Material and Method}

The present study is part of the project "Atherosclerotic cardiovascular disease, lipemic disorders, hypertension, obesity and diabetis mellitus in a population of the Metropolitan Area of S. Paulo, SP, Brazil", carried out in Cotia county, located in the outskirt of
S. Paulo city. The methodology adopted in the research is described in earlier study ${ }^{1 R}$. The sample was taken from 1990-1991.

An approach was adopted with a view to delimiting typical social groupings, i.e., social classes, which should correspond to typical models of living and insertion into urban life and historically determined. The actual basis for the definition of the social groupings were socio-economic and geographical criteria, on the basis of which certain "study areas" were delimited at various geographical points within the city - both centrally placed and on the outskirts- each of which corresponded to different living conditions, in accordance with a gradient of socioeconomic levels.

The operationalization of the concept of social class was based on Singer ${ }^{2 k}$ and Lombardi ${ }^{17}$. Four social classes were defined on the basis of information gathered through interviews, of socio-economic nature, such as occupation, position within occupation, ownership of property and its size, number of employees if any, schooling and income, both with regard to the person interviewed and the head of the family. The four classes may be characterized as follows:

I- employer/owners with more than five employees or professionals of universitary level;

II- small owners with fewer than five employees, primary or intermediate level of schooling and earning montly more than five legal minimum salaries (approximately 350 dolars);

III- salaried employees with working skills and primary or intermediate level of schooling;

IV- under-employed or small property owners, generally with no permanent employment, with no working skills and with a montly income of less than five legal minimum salaries.

Further, data were collected, by means of interviews, as to iife style with regard to smoking consumption of alcohol and sedentary habits, defined as follows:

- smoker, a person who said that be smoked 10 or more cigarrettes per day;

- a drinker, a person who replied afirmatively to the relevant questions of the CAGE questionnaire ${ }^{19}$;

- a sedentary person, one of light dally physical activity. Physical activity was defined according to the three categories: light, moderate and intense, in accordance with the profile of daily energy expenditure of the individual 
expressed as multiples of the Basic Metabolic Rate (BMR), i. e., light activity <1.64 BMR; moderate activity 1.64-1.82 BMR and intense activity $>1.82 \mathrm{BMR}^{25}$.

Obesity was defined as the relationship weight $/$ height $^{2}$ for values $>=30 \mathrm{~kg} / \mathrm{m}^{2}$ ( $>=6.25$ $\left.\mathrm{lbs} / \mathrm{ft}^{2}\right)^{4}$.

Hypertension was defined by the values $>=160 \mathrm{mmHg}$ for systolic and $>=95 \mathrm{mmHg}$ for diastolic pressure ${ }^{13}$.

Hypercholesterolemia was defined according to the values for total serum cholesterol, being considered borderline-high for the values $>=200 \mathrm{mg} / \mathrm{dl}$ and high for those $>=240 \mathrm{mg} /$ $\mathrm{dl}$; normal levels for the HDL -cholesterol was defined thus: $35 \mathrm{mg} / \mathrm{dl}$ for $\mathrm{men}$ and $>=45 \mathrm{mg} / \mathrm{dl}$ for women ${ }^{22}$.

The simple population was composed of 1,049 people, 8 cases was lost due uncompleted information. The pilot project carried out in "study area 1" was excluded as the data gathered there on socio-economic conditions were of doubtful value.

\section{Statistics Employed}

The arithmetical averages of the percentages of smokers, drinkers and people of sedentary life style were calculated for each social class stratified by sex and age. The social classes were standardized in accordance with age by the direct method ${ }^{27}$ to make possible to draw up a comparison of the differentials between them, then tested by the Khi-squared method. Six models of multiple regression were constructed for each of four lipemic situations in which the lipid levels appear as dependent variables:

Lipemic disorders characterized by a total cholesterol level above $220 \mathrm{mg} / \mathrm{d}$ ] and triglyceride above $150 \mathrm{mg} / \mathrm{d} 1$ :

First equation - total cholesterol as the dependent variabie with the following independent variables: age, sex, smoking, alcohol consumption, sedentary life style, hypertension and obesity.

Second equation - In triglycerides as the dependent variables with the following independent variables: age, sex, smoking, alcohol consumption, sedentary life style, hypertension and obesity.

Lipemic disorders characterized by HDLcholesterol levels equal to or bellow $45 \mathrm{mg} / \mathrm{di}$ for women and equal to or bellow $35 \mathrm{mg} / \mathrm{dl}$ for men, with that for triglyceride greater than or equal to $150 \mathrm{mg} / \mathrm{d}$ ].

Third equation - In triglycerides as the dependent variable with the following independent variables: age, sex, smoking, alcohol consumption, sedentary life style, obesity, hypertension.

Four equation - HDL-cholesterol as the dependent variable with the following independent variables: age, sex, smoking, alcohol consumption, sedentary life style, hypertension and obesity.

Lipemic disorders characterized by serum levels HDL -cholesterol equal to or bellow $45 \mathrm{mg} /$ $\mathrm{dl}$ for women and equal to or bellow $35 \mathrm{mg} / \mathrm{dl}$ for men with triglycerides bellow $150 \mathrm{mg} / \mathrm{dl}$.

Fifth equation - HDL-cholesterol as dependent variable with the following independent variables: age, sex, smoking, alcohol consumption, sedentary life style, hypertension and obesity.

Lipemic disorders characterized by total cholesterol serum levels equal to or above $220 \mathrm{mg} / \mathrm{dl}$ with triglycerides bellow $150 \mathrm{mg} / \mathrm{dl}$.

Sixth equation-total cholesterol as the dependent variable with the following independent variables: age,sex, smoking, alcohol consumption, sedentary life style, hypertension and obesity.

The data were codified in the following way: sex,$-I=$ female and $1=$ male;

smoking, $-1=$ no and $1=y e s$;

drinking, $-1=$ no and $1=$ yes;

physical activity, $-1=$ sedentary and $1=$ moderate or intense;

obesity, $-1=$ no and $1=y e s$;

hypertension, $-1=$ no and $1=$ yes.

Cholesterol total, HDL-cholesterol and triglycerides are taken as continuos variables.

\section{Results}

The distribution of habits of living expressed by smoking, drinking and sedentary life style between men and women, by social class, standardized by age, is to be found in Table 1 .

As regard smoking, it is to be noted that the habit is more prevalent among men and uniformly distributed among the social classes, without there being any statistically significant 
Table 1. Smoking, drinking and sedentary life style by social class, age standardized*. Cotia county, 1990-91.

\begin{tabular}{|c|c|c|c|c|c|c|c|c|c|c|c|c|c|c|}
\hline \multirow{3}{*}{$\begin{array}{l}\text { Social } \\
\text { Class }\end{array}$} & \multicolumn{7}{|c|}{ Men } & \multicolumn{7}{|c|}{ Women } \\
\hline & \multicolumn{3}{|c|}{ Smoking } & \multicolumn{2}{|c|}{ Drinking } & \multicolumn{2}{|c|}{ Sedentary life } & \multicolumn{3}{|c|}{ Smoking** } & \multicolumn{2}{|c|}{ Drinking } & \multicolumn{2}{|c|}{ Sedentary life*** } \\
\hline & $\mathrm{n}$ & $c$ & $\%$ & $c$ & $\%$ & $\mathrm{c}$ & $\%$ & $c$ & $\mathbf{n}$ & $\%$ & $\mathrm{c}$ & $\%$ & c & $\%$ \\
\hline 1 & 35 & 17 & 45.3 & 6 & 9.9 & 17 & 47.2 & 43 & 17 & 40.7 & 0 & 0.0 & 8 & 18.9 \\
\hline II & 90 & 34 & 38.5 & 16 & 11.9 & 35 & 40.1 & 96 & 18 & 18.4 & 0 & 0.0 & 35 & 40.9 \\
\hline fll & 219 & 86 & 42.5 & 29 & 12.2 & 81 & 36.3 & 336 & 86 & 26.4 & 3 & 0.9 & 122 & 30.9 \\
\hline IV & 84 & 36 & 43.4 & 14 & 18.2 & 35 & 40.0 & 138 & 26 & 13.6 & 1 & 0.7 & 55 & 42.4 \\
\hline Total & 428 & 173 & 40.4 & 63 & 14.7 & 168 & 39.2 & 613 & 147 & 23.9 & 4 & 0.7 & 220 & 35.9 \\
\hline
\end{tabular}

* Standardized by direct method

** $1-2 p<0.21-4 p<0.02$

$* * * 1-2-3-4 p<0.021 .2 p<0.051-3 p<0.021 .4 p<0.023 .4 p<0.02$

differences among them. Among women the prevalence is considerable in the class of highest socio-economic level. Drinking is a habit basically to be found among men, with lesser prevalence, though of no statistical significance, in the class of highest socio-economic level. With regard to physical activity it is seen that more than $40 \%$ of the population under study is sedentary, with exception of women of the highest socio-economic level and men and women of the skilled working class.

On the other hand the attempt has also been made to detect the proportion in wich the above-mentioned habits may be predective of lipemic disorders. Individuals were grouped them, for this purpose, according to lipemic disorders, not necessarily in obedience to
Fredickson's classification. In view of the characteritics of the population - predominantly young - it was decided to work with moderate hypercholesterolemia (serum levels of total cholesterol $>=220 \mathrm{mg} / \mathrm{dl}$ ) so as not to run the risk of obtaining a group restricted to elderly people and thus lose the effect of the variable age. The same reasoning guided the choice of the thresholds for the concentration of triglyceride ( $>=150 \mathrm{mg} / \mathrm{dl}$ ).

The Table 2 presents the mentioned models of multiple regressions with their respective Coefficients of Multiple Determination $\left(\mathrm{R}^{2}\right)$ which give the proportion in which the dependent variable is explained by the independents variables - age, sex, smoking, drinking, (sedentary ) activity, obesity and hypertension.

Table 2. Multiple regressions among indicators of lipemic disorders (dependent variables) and age (A), sex (S), use of tobacco (T), physical activity $(\mathrm{Ph})$, alcohol consumption (Al) obesity $(\mathrm{O})$ and hypertension (H) (independent variables).

\begin{tabular}{|c|c|c|c|}
\hline Lipemic Levels & Dependent Variable & Equation & $\mathrm{A} 2$ \\
\hline \multirow[t]{2}{*}{$\begin{array}{l}\text { Total cholesterol }>=220 \mathrm{mg} / \mathrm{dl} \\
\text { Triglycerides }>=150 \mathrm{mg} / \mathrm{dl}\end{array}$} & Total cholesterol (C) & $\begin{array}{c}C=177.3+0.27 \mathrm{~A}+14.4 \mathrm{~T}+ \\
13.0 \mathrm{Al}+21.8 \mathrm{OT}+0.34 \mathrm{PhA}+ \\
12.3 \mathrm{Al} \mathrm{T}+18.0 \mathrm{SO}\end{array}$ & 0.22 \\
\hline & In Triglycerides (TG) & (Ii) & 0.19 \\
\hline \multirow{2}{*}{$\begin{array}{l}\text { Triglycerides }>=150 \mathrm{mg} / \mathrm{dl} \\
\mathrm{HDL} \text { cholesterol }<=45 \mathrm{mg} / \mathrm{d} \\
\text { (women) and }<=35 \mathrm{mg} / \mathrm{dl} \text { (men) }\end{array}$} & In Triglycerides (TG) & $\mathrm{TG}=3.79 \cdot 1.72 \mathrm{Ph}(\mathrm{III})$ & 0.22 \\
\hline & HDL-cholesterol (HDL) & $\begin{array}{c}H D L=11.2+0.43 \mathrm{~A}-20.60- \\
0.52 \mathrm{TA} \text { (IV) }\end{array}$ & 0.31 \\
\hline
\end{tabular}

HDL cholesterol $<=45 \mathrm{mg} / \mathrm{dl}$ (women), $<=35 \mathrm{mg} / \mathrm{d}$ ! (men), Triglycerides $<150 \mathrm{mg} / \mathrm{dl}$ 
For the lipemic state characterized by the concentration of total cholesterol $>=220 \mathrm{mg} / \mathrm{dl}$ and of triglycerides $>=150 \mathrm{mg} / \mathrm{dl}$ two multiple regression equations were constructed in the first of which total cholesterol was the dependent variable and in the second of which the natural logarithm of the concentration of triglyceride was. It is to be seen that the levels of total cholesterol (first equation) are significatly associated $(\mathrm{p}<0.05)$ with the variables age, smoking, drinking and with the interations sedentary physical activity/age and drinking/smoking giving $\mathrm{R}^{2}$ equal to $22 \%$. In the second equation the natural logarithm of the triglycerides is the dependent variable (thus obtaining normal distribution) and showed no significant association with any of the independent variables, though altogether they account $\left(R^{2}\right)$ for $19 \%$ of the variations in the triglycerides levels when expressed in this way.

In the lipemic condition in which the levels of HDL-cholesterol were $<45 \mathrm{mg} / \mathrm{dl}$ for women and $<35 \mathrm{mg} / \mathrm{dl}$ for men, accompanied by triglycerides levels $>=150 \mathrm{mg} / \mathrm{dl}$ (third equation) the HDL- cholesterol showed direct association with age and an inverse association with obesity and the interation smoking/age (possibly expressing the duration the habit), with $\mathrm{R}^{2}$ equal to $31 \%$. In this turn, the natural logarithm of the triglycerides concentration (fourt equation) is inversily associated with light physical activity, with $\mathrm{R}^{2}$ equal to $22 \%$.

Table 3 gives the weight of each independent variable, linked to the regression models already presented, by means of the $B$ standardized coefficient and respective descriptive levels: in the first equation, for example, the interaction of the variables smoking/obesity represents twice that of drinking and $40 \%$ more than smoking alone in the prediction of the levels of total cholesterol in the moderate hypercholesterolemia accompanied by triglycerides levels above $150 \mathrm{mg} / \mathrm{dl}$.

In the fourth equation, for each increase of one year there is corresponding diminution of $2.94 \mathrm{mg}$ of HDL-cholesterol in the obese when below normal levels of this constituent are accompanied by triglycerides levels above $150 \mathrm{mg} / \mathrm{dl}$. On the other hand, in the fifth equation it is found that there is an increase in the risk of hypercholesterolemia for the male sex, and a greater effect is registered in the interaction of the variables sex/obesity.

Table 3. Relative weight (standardized B coefficient) ${ }^{2}$ of variables age (A), sex (S), use of tabacco (T), aicohol consumption (Al), physical activity $(\mathrm{Ph})$, obesity $(\mathrm{O})$ in the prediction of lipemic state in multiple regressions.

\begin{tabular}{|c|c|c|c|c|}
\hline Lipemlc States & $\begin{array}{l}\text { Dependent } \\
\text { Variable }\end{array}$ & $\begin{array}{l}\text { Independent } \\
\text { Varlable }\end{array}$ & $\begin{array}{c}\text { Standardized } \\
\mathrm{B}\end{array}$ & $\begin{array}{l}\text { Descriptive } \\
\text { Level }\end{array}$ \\
\hline $\begin{array}{l}\text { Total cholesterol }(\mathrm{C})>=220 \mathrm{mg} / \mathrm{dl} \\
\text { Triglycerides }(T G)>=150 \mathrm{mg} / \mathrm{dl}\end{array}$ & Total cholesterol (C) & $\begin{array}{c}\text { age (A) } \\
\text { sex (S) } \\
\text { tobacco (T) } \\
\text { alcohol (Al) } \\
\text { OT } \\
\text { Phl } \\
\text { AIT } \\
\text { SO }\end{array}$ & $\begin{array}{l}0,1638 \\
\\
0,6988 \\
0,4382 \\
0,9210 \\
0,5296 \\
0,5486 \\
0,4148\end{array}$ & $\begin{array}{l}0,069 \\
0,016 \\
0,019 \\
0,003 \\
0,018 \\
0,016 \\
0,048\end{array}$ \\
\hline $\begin{array}{l}\text { Chalesterol total }(C)>=220 \mathrm{mg} / \mathrm{dl} \\
\text { Triglycerides }>150 \mathrm{mg} / \mathrm{dl}\end{array}$ & Cholesterol total (C) & $\begin{array}{c}\text { sex (S) } \\
\text { OT } \\
\text { SO }\end{array}$ & $\begin{array}{l}3,836 \\
4,390 \\
5,024\end{array}$ & $\begin{array}{l}0,067 \\
0,030 \\
0,018\end{array}$ \\
\hline $\begin{array}{l}\text { Triglycerldes (TG) }>=150 \mathrm{mg} / \mathrm{dl} \\
\mathrm{HDL} \text { cholesterol }(\mathrm{HDL}) \\
<=45 \mathrm{mg} / \mathrm{dl} \text {-women } \\
<=35 \mathrm{mg} / \mathrm{dl} \text { - } \text {-men }\end{array}$ & $\begin{array}{l}\text { Triglycerides } \\
\text { (TG) } \\
\text { HDL cholesterol } \\
\text { (HDL) }\end{array}$ & $\begin{array}{l}\text { Physical } \\
\text { activity } \\
\text { age (A) } \\
\text { obesity (O) } \\
\text { TA }\end{array}$ & $\begin{array}{r}-3,828 \\
1,102 \\
-2,948 \\
-3,356\end{array}$ & $\begin{array}{l}0,019 \\
0,019 \\
0,026 \\
0,021\end{array}$ \\
\hline
\end{tabular}

2 Beta $k=B k$ (SK/Sy) where Bk and Sy are, respectively the B coefficient and the standard desviation of the $\mathrm{k}$-th independent variable and Sy the standard desviation of the dependent variable. 


\section{Comentary}

The distribution of the components of the life style represented by drinking, smoking, and sedentary activity among the classes express cultural habits in relation to which these grouping have established strategies of survival, including leisure and others aspects of the social life. Table 1 shows that these habits are to be found more or less uniformly throughout social groups, with no sigrificants differences. For example, the proportion of sedentary individuals varied between 40 and $59 \%$, approximately, with the exception of the women belonging to class of highest socio-economical level $(27.3 \%)$. Probabily self-care are to be found among women of this class who have time available for physical exercise, instead of the domestic work in large houses, account for his result. A different situation is found in the others classes of lower acquisitive power in which is common for women to live inactively in small rooms bare of furniture or other comforts. The men belonging to the class of higher socio-economic level are sedentary in the measure in which the great majority of them dedicate their time to working activities in offices or to intellectual work, and also relegate selfcare to second place, a fact brought to ligh by this study project. On the other hand, salaried workers, as a result of the type of local industry dedicate their time to light activities and under employed, unskilled, are mainly watchmen or odd-jobs men: and these latter, though they engage in activities which demand physical effort, spend job-less periods because of the lack of demand for labor.

Smoking is of more or less uniform prevalence of between 40 and $50 \%$, approximately, involving the men of all the classes and the women of higher socio-economic level, who stand out from the others by virtue of their economic independence.

Alcohol consumption is seen to be a habit of greater prevalence in the classes of lower socio-economic level. Among the small shopkeepers for example, there are many owners of bars frequented by laborers for whom it is the only leisure option on the out-skirts of the city, thus possibly leading part of this population into this habit.

As regards the lipemic conditions dealt with in the regression equations, the choice of them was made by virtue of questions raised as to role of the triglycerides and of HDL-cholesterol as a risk factor in atherosclerotic cardiovascular disease ${ }^{1,2,3,5, R, 9,21,30}$. In some studies triglycerides have been indicated as an independent risk factor and in others when counfusing variables such as arterial pressure, smoking, phisycal activity and glucose metabolism indicators are controlled the effect of this constituent, in the assotiations established, diminishes considerably ${ }^{25}$. On the other hand, it has been demonstrated that HDL-cholesterol by itself, wheter or not in the presence of hypercholes-terolemia has a negative association with mortality by atherosclerotic cardiovascular disease, when accompanied by high triglycerides levels, they increase the risk of these disease $\mathrm{s}^{6,10,155,20,21,24}$. It has been demonstrated that these lipemic states are related to hyperinsulinemia, centralized obesity, resistense to insulin and hypertension, among others, in such a way that they leave the way open for further research into the inter-relationships between triglycerides and the control of the metabolism of HDL-cholesterol.

In this study it is seen in all the equations that the seven independent variables account for the variations in the lipemic levels in proportions that vary between 20 and $30 \%$, approximately. Other factors of a genetic nature or eating habits probably act with greater intensity in the determination of lipemic conditions and, thus, for a fuller explanation of non-transmissible diseases a Genetic Epidemiology has proposed, on the basis of a series of theories, which seek an etiology for these morbidities based on genetic and environmental factors ${ }^{24}$.

It should also be emphasized that in the presence of low triglycerides levels (of less than $150 \mathrm{mg} / \mathrm{dl}$ ) hypercholesterolemia is associated with the variables sex and the interactions obesity/smoking and sex/smoking, while in the presence of levels above $150 \mathrm{mg} / \mathrm{dl}$ significant associations were found with a greater number of variables (age, smoking, alcohol consumption and the interactions with the variables obesity/smoking, physical activity/age and alcohol consumption/smoking, maintaining, even so, values close to those for Coefficients of $\mathrm{Mul}$ tiple Determination $\left(\mathrm{R}^{2}\right)$.

As regards HDL-cholesterol, the inverse association between this constituent and obesity and smoking, already described in the literature, was only discovered in the presence of 
triglycerides levels higher than $150 \mathrm{mg} / \mathrm{dl}$, under these conditions, the Coefficient of Multiple Determination $\left(\mathrm{R}^{2}\right)$ was the highest registered for any of the regression models proposed, attaining a value of $31 \%$ ( fourth equation, Table 2). It also appears that, in this lipemic condition, sedentary life style acts on HDL-cholesterol by means of the effect it exercises on the triglycerides (third equation, Table 2); as for this aspect, similar results were found by Patsch et al ${ }^{23}$.

In their turn, the standardized B coefficients (Table 3) demonstrate that smoking and the interation obesity/smoking exercise greater explanatory effect with regard to the serum levels of total cholesterol, in the first equation, when the serum cholesterol levels were associated with triglyceride concentrations higher than $150 \mathrm{mg} / \mathrm{dl}$. On the other hand, in the lipemic state characterized by low levels of HDL-cholesterol and triglycerides levels greater than $150 \mathrm{mg} / \mathrm{dl}$, the interaction smoking/age possessed greater weigh than obesity.

Thus it is to be seen in this study that constituent elements of life style represented by smoking, alcohol consumption and sedentary activity are to be found in all the social classes. They are also demonstrably explanatory factors of the lipemic conditions which determine the morbidities which are a part of the etiology of the atherosclerotic cardiovascular diseases.

\section{References}

1. ABBOTT, R. D. et al. High density lipoprotein cholesterol. total cholesterol screening, and miocardial infarction. Arterioscierosis, 8:207-11, 1989.

2. ARNTZENIUS, A.C. Regresion of atherosclerosis: benefit can be expected from low LDL cholesterol and high HDL cholesterol levels. Acta Cardiol., 46: 431-8,1991.

3. BETTERJDGE, J. High density ljpoprotein and coronary heart disense: how it protects is still a mystery, $B M J$ 298: 974-5, 1989.

4. BRAY, G.A. Obesity definition, dingnosis, and disavantages, Med. J. Australia, 142:52-8, 1985.

5. CASTELLI, W.P. et al. Incidence of coronary heart disease and lipoprotein cholesterol levels: The Framingham. study. JAMA, 256: 2835-8, 1986.

6. CASTELLI, W. P. Triglycerides and serum choiesterol (letter). Postgrad Med. 90: 47-53, 1991.

7. CASTELLS, M. ?Que és sociologica urbana? In: Castells, $M$. Problemas de investigación en sociologia, urbana. Madrid, Siglo Vienteuno de España Ed., [971, p.15-45.

8. GARBER, M.A. et al. Screening asymptomatic adults for cardiac risk factors: the serum cholesterol level. Ann. of Inter. Med., 110: 622-39, 1989.

9. GARRISON, R. J. et al. Cigarrete smoking and HDL cholesterol: the Framingham study. Atheroscierosis, 30: $17-35,1978$.
10. GOLDBOUR, V. \& MEDALIE, J. H. High density lipoprotein cholesterol and incidence of coronary heart disease-The Israeli Ischaemic Heart Study. Am.J. Epidemiol., 109:296-308,1979.

11. GRUNDY, M.S. et al. The place of HDL cholesterol management: a perspective from the National Cholesterol Education Program. Arch. Intern. Med., 149:505-10,1989.

12. HEYDEN, S. et al. The combined effect of smoking and coffee drinking on LDL and HDL cholesterol. Circulation, 60: 22- 5, 1979.

13. JOINT. The 1988 Report. National Commitee on Detection, Evaluation, and Treatment of High Blood Pressure, Arch.Intern. Med., 148:1023-38,1988.

14. KEIL, U. Alcohol and blood pressure and its interaction with smoking and other behavioural variables results from MONICA Augsburg Study 1984-1985 J. Hypertension, 9: 491-8, 1991.

15. LAWS, A, et al, Relation of fasting plasma insulin concentration to high density lipoprotein cholesterol and triglyceride concentration in men. Arteriosclerosis thrombosis, 6:1636.42, 1991 .

16. LINN, S, et ai. Serum total cholesterol: HDL cholesterol ratios in US white and black adults by selected demographic and socio-economic variables (HANES II). Am J. Public Healih, 81:1038-43,1991.

17. LOMBARDI, C. et al. Operacionalização do concejto de classes sociais em estudos epidemiológicos. Rev. Saúde Pública, 22: 253-65, 1988.

18. MARTINS, I. S. et al. Doenças cardiovascuiares ateroscleróticas, dislipidemias, hipertensão, obesidade e diabetes melito em populaçāo da área metropolitana da regiăo Sudeste do Brasil. I-Metodologia da pesquisa. Rev. Saúde Pública, 27: 250-61,1993.

19. MASUR, J, et al. Detecçâto precoce do alcoolismo em clínica através do questionário CAGE. J. Bras. Psiqu., 34:31-4,1985.

20. MILLER, G. J. \& MILLER, N. E. Plasma high density lipoprotein concentration and development of isquemic heart disease. Lanceff, 1:16-9, 1975.

21. NHI CONSENSUS CONFERENCE. Triglyceride, high density lipoprotein, and coronary heart disease. JAMA, 269:505-10, 1993.

22. NATIONAL CHOLESTEROL EDUCATION PROGRAM: report of the Expert Panel on Detection, Evaluation and Treatment of Cholesterol in Adults; United States US Department of Health and Human Services, 1989. (NHI publication No 89-2925).

23. OHARA, K. et al, Factors associated with high density lipoprotein cholesterol in Japaneses and American telephone executives. Am. J. L. Epidemiol, 134:137$48,1991$.

24. PATSCH, W. et al. Relation of high density lipoprotein cholesterol and its subfractions to Apolipoprotein Cholesterol and apolipoprotein A-I and fasting triglycerides: the role of enviromental factors. Am J. Epidemiol., 136:546-57,1992.

25. REUNIONCONSULTIVA CONJUNTA FAO/OMS/UNU DE EXPERTOS, Roma, 1981. Necessidades de energia y de proteina informe. Ginebra, Organizacion Mundial de la Salud, 1985. (OMS- Serie de Informes Técnicos, 724).

26. ROSEMBERG, J. Tabagismo: sério problema de Saúde Páblica no Brasil. São Paulo, Almed-Edusp, 1991. p. $137+65$.

27. SANTOS,J. L. Principais técnicas de anólise e projeçæo. In: Santos.J. L. org et al. Dinamica de populaçāo: teoria métodos e técnicas. Săo Paulo, T.A. Queiróz, 1980, p.103-55.

28. SINGER, P. I. Dominaçāo e desighualdade. Rio de Janeiro, Paz e Terra, 1981. 
29. SORENSEN,T. I. A. Genetic epidemiology utilizing the adoption method; studies of obesity and of premature denth in adults. Scand. J. Soc. Med., 19:14-19, 1991.

30. SPAGNOLO, A. et al. High density lipoprotein cholesterol distribution and predictive power in some Italian populations studies. Eur.J. Epidemiol., 5:328-35, 1989.

31. WOLF, R.N. \& GRUNDY,S,M. Influence of weight reduction on plasma lipoprotein in obese patients. Arteriosclerasis, 3:160-9,1983.

\section{Resumo}

O estudo, parte do projeto "Doenças cardiovasculares ateroscleróticas, dislipidemias, hipertensáo, obesidade $\theta$ diabetes melito em populaçāo da área metropolitana da regiāo Sudeste do Brasil", teve os seguintes objetivos: a)caracterizar a distribuiçäo da prevaléncia de tabagismo, etilismo e sedentarismo entre grupamentos humanos típicas, do ponto vista socioeconómico; b)- estabelecer associaçōes entre os hábitos e morbidades citados $\theta$ determinados estados lipêmicos. A prevalència dos hábitos em questäo comportou-se da seguinte forma: tabagismo, predominou entre os homens, com prevalência média de $45 \%$, uniformemente distribuida entre as classes; entre as mulheres o percentual médio foi de $22,5 \%$, com diterença significante para a classe de mais alto nivel socioeconómico, com 46,3\%. O sedentarismo apresentou alta prevalencia, entre homens a mulheres, entre $40 \%$ e $50 \%$, nāo havendo diferenças estatisticamente significantes entre os sexos e nem tampouco entre as classes. $O$ etilismo foi um hábito fundamentalmente difundido entre os homens, sem diterencas de prevalencla estatisticamente significantes entre as classes. Para o estabelecimento de associaçбes entre hábitos e estados lipemicos foram escolhidas quatro situaçores. com as seguintes caracteristicas: 1 - Hipercolesterolemia moderada acompanhada de nivels súricos de triglicérides menores ou iguais e malores de $150 \mathrm{mg} / \mathrm{dl} ; 2$ 2- HDL colesterol sérico abaixo da normalidade acompanhado de niveis de triglicerides iguais ou malores de $150 \mathrm{mg} / \mathrm{dl}$ ou menores de $150 \mathrm{mg} / \mathrm{dl}$. Foram estabelecidos sels modelos de regressêo múltipla, com sete variáveis independentes - idade, sexo, tabagismo, etilismo, sedentarismo, hipertensấo ө obesidade. Na primelra situaçāo lipëmica houve assoclaçōes significantes entre a hipercolesterolemia, acompanhada de niveis de triglicérides $>=150 \mathrm{mg} / \mathrm{dl}$, com as seguintes variáveis independentes: idade, tabagismo e as interaços entre obesidade/tabagismo, sedentarismo e sexo/obesidade, com $R^{2}$ igual $22 \%$; as variáveis de malor peso na prediçāo da variaçāo dos niveis de colesterol total foram o tabagismo e a interaçâo entre obesidade/tabagismo. A hipercolesterolemia acompanhada de niveis de triglicérides menores do que 150mg/dl associou-se às seguintes varláveis: sexo, interaçöes obesidade/tabagismo e sexo/obesidade. Para a situaça 2- o HDL colesterol, acompanhado de nivels de triglicérides $>=150 \mathrm{mg} / \mathrm{d}$, associou-se inversemente as variáveis obesidade $\theta$ a interaçäo tabagismo/ idade e diretamente à ldade $\left(R^{2}=31 \%\right.$ ); as variáveis obesidade e a interaça tabagismo/dade apresentaram peso três vezes malor do que a jade na explicaça da variaçáo dos niveis séncos do HDL colesterol. Na presença de niveis séricos de triglicérides menores do que $150 \mathrm{mg} / d$ l năo houve qualquer assoclaçăo com as variáveis aludidas e o conjunto apresentou $A^{2}$ igual a $22 \%$. Fica evidente, que as associaçós inversas entre HDL-colesterol com o tabagismo e obesidade, já descritas na liferatura, so ocorreram na presenca de niveis de triglicérides $>=150 \mathrm{mg} / \mathrm{dl}$. Constata-se que na presença de baixos niveis de triglicérides diminui o numero de variaveis preditivas da hipercolesterolemia. Em síntese, na populaçăo abordada, os hábitos componentes do estilo de vida (tabagismo, etilismo e sedentarismo), que se constituem em fatores de risco de morbidades determinantes das doenças cardiovasculares aterosclerotices, encontram-se distribuidos em todos os grupamentos sociais tipicos nesta deteminada forma de organizaçazo social. Por outro lado, as sete variáveis independentes utilizadas nos modelos de regressāo múltipla apresentaram coeficientes de determinaçăo múltipla, que variararn entre $20 \ominus 30 \%$ aproximadamente. Ressalta-se, desta forma, a importáncia da epidemiologia genática no estudo das morbidades em questāo.

Fumo, epidemiologia. Alcoolismo, epidemiologia. Estilo de vida. 